\title{
Worsening anatomic outcomes following aflibercept for neovascular age-related macular degeneration in eyes previously well controlled with ranibizumab [Corrigendum]
}

\author{
Nudleman E, Wolfe JD, Woodward MA, Yonekawa Y, \\ Williams GA, Hassan TS. Clinical Ophthalmology. 2016;10: \\ 1053-1057.
}

A units error was published on page 1055 , column 2, as "3.1\%"; the correct units are " $\mu \mathrm{m}$ " $(3.1 \mu \mathrm{m})$.

Clinical Ophthalmology is an international, peer-reviewed journal covering all subspecialties within ophthalmology. Key topics include: Optometry; Visual science; Pharmacology and drug therapy in eye diseases; Basic Sciences; Primary and Secondary eye care; Patient Safety and Quality of Care Improvements. This journal is indexed on

\section{Dovepress}

PubMed Central and CAS, and is the official journal of The Society of Clinical Ophthalmology (SCO). The manuscript management system is completely online and includes a very quick and fair peer-review system, which is all easy to use. Visit http://www.dovepress.com/ testimonials.php to read real quotes from published authors. 